\title{
Effect of petroleum hydrocarbon pollution on the nutritional value of ripe guava (Psidium guajava) fruits grown in Imo State, Nigeria
}

\author{
L. A. NWAOGU * and C. O. UJOWUNDU \\ Department of Biochemistry, Federal University of Technology Owerri, Nigeria. \\ *Corresponding author, E-mail: nwogulinus@yahoo.com
}

\begin{abstract}
The effect of petroleum hydrocarbon pollution on the nutritional value of two varieties of ripe edible guava (Psidium guajava) fruits harvested from a petroleum hydrocarbon-polluted locality, Umudike, in Egbema were investigated. The results obtained were compared to identical guava fruits from an unpolluted area of Uvuru in Aboh Mbaise which served as control. There was no significant difference $(\mathrm{P} \geq 0.05)$ observed in the proximate compositions from the two guava fruit varieties and from the two localities respectively. The proximate compositions include ash, carbohydrate, crude protein, crude fibre, fats and moisture content. Petroleum hydrocarbon pollution did not affect significantly the mean values of mineral elements in the guava fruits from the two localities. The mineral elements were calcium, phosphorus, iron, magnesium, potassium and sodium. The glucose concentrations in Psidium guajava fruit samples from both environments were essentially similar. However, the mean value concentrations in $\mathrm{mg} / 100 \mathrm{~g}$ and iu/100g for ascorbic acid and $\beta$ carotene respectively from Umudike in Egbema were lower $173.28 \pm 0.77$ for red variety and $164.75 \pm 0.89$ for white compared to those from Uvuru Mbaise which gave $189.20 \pm 1.23$ for red and $180.29 \pm 1.18$ for white variety respectively. The $\beta$-carotene concentrations of $204.60 \pm 7.92$ for red and $173.47 \pm 8.80$ for white compared to those from Mbaise which gave $249.60 \pm 13.19$ and $228.54 \pm 23.57$ for red and white varieties respectively. The results revealed that ascorbic acid and $\beta$-carotene proved responsive to pollution due to petroleum hydrocarbon found in Egbeme. The biochemical implications of these findings were discussed. (C) 2010 International Formulae Group. All rights reserved.
\end{abstract}

Keywords: Ascorbic acid, glucose, $\beta$-carotene, environment, biochemical, proximate, mineral compositions.

\section{INTRODUCTION}

Nigeria is a major world producer of crude oil. Pollution due to oil spillage and gas flaring has steadily increased as a result of oil exploration. In the Niger Delta alone, there have been over 550 reported cases of crude oil spillage since 1996, releasing 2.8 million barrels of crude oil into the environment (Kori-Siakpere, 1998; Odiete, 1999). When petroleum hydrocarbon is ingested or absorbed within the cells or tissues of plants or animals lead to the generation of reactive intermediates (Baker, 1970). Oil spillage has been known to exhibit various deleterious effects on plants by generally retarding plant growth (Gill and Sandota, 1974; Glouse et al, 1980; Ekpo and Nwankpa, 2005); reduces aeration, by blocking air spaces between soil particles hence create condition of anaerobiosis (Rowell, 1977), and causes root stress which reduces leaf growth thereby impairing photosynthesis (Smith et al, 1989). Baker (1970) reported that when crude oil penetrate and accumulate in plants, it causes

(C) 2010 International Formulae Group. All rights reserved. 
damage to cell membranes and leakage of cell contents. Udo and Fayemi (1975) also reported that growth of plants was affected in crude oil - polluted soil, chlorosis of leaves resulted and the plants were dehydrated.

The soil provides the direct mineral element reserves from which terrestrial plants (e.g. guava) obtain their required nutrients. These mineral elements are available to plants after the solid phase of the soil has released them into solution by solubilization and ion exchange (Epstein, 1972). Any condition that disrupts the normal plant - water relationship of the root within the soil will negatively affect the normal growth of the plant.

Guava (Psidium guajava) is a small tree with spreading branches. It belongs to the family Myrtaceae and is grown in southeastern Nigeria for its fruits (Umoh, 1998). The fruit when ripe exudes a strong, sweet and musty odour. It may be round, ovoid or pear shaped of about 5 to $10 \mathrm{~cm}$ long. There are two varieties, the reddish and creamy white in colour. The central pulp is juicy and normally filled with hard brownish seeds; though some species have soft chewable seeds (Jimenez et al, 2001). It is easy to recognize because of its smooth, thin, copper - coloured bark that flakes off, showing the greenish layer beneath. The leaves have medicinal properties and as such used in the treatment of some ailment especially stomach problems (Sofowara, 1983).

The fruit is eaten fresh but is principally used for the preparation of jellies and jams; it contains $82 \%$ water, $0.7 \%$ protein, $11 \%$ carbohydrate and a fairly good amount of vitamins $\mathrm{A}, \mathrm{B}_{1}, \mathrm{~B}_{2}$ and $\mathrm{C}$ including some minerals. The tree is native to America but is now present in every tropical and subtropical country (Sampson, 1986). After a major oil spillage, it was observed that the main crops affected most were tubers, root crops, shrubs and tree plants (Odu, 1972).

The choice of Umudike Village in Egbema for the source of fruit samples stemmed from the observation that in Imo state, oil wells are concentrated more in Ohaji-Egbema and Uguta areas where major oil exploration and mining activities have been going on over the years and also there has been reported cases of oil pollution in Umudike Egbema, the opposite is the case in Uvuru Mbaise.

This study was therefore designed to assess the effect of petroleum hydrocarbon pollution on the nutritional value with special emphasis on ascorbic acid, $\beta$-carotene and glucose concentrations of ripe guava (Psidium guajava) fruits as these parameters are indices of stress in plants and animals.

\section{MATERIALS AND METHODS Collection of fruit samples}

Five fresh fruit samples from each guava tree of the two varieties (red and creamy white) ripe guava used for this study were collected from Umudike village in Egbema, a PHC polluted locality, and Uvuru in Aboh Mbaise served as the control. The two locations are both in Imo State, Nigeria.

\section{Sample preparation and extraction}

Ten grammes of the ripe Psidium guajava pulps from each variety and locality were mixed with $100 \mathrm{ml}$ of distilled water and ground into fine particles using a kitchen blender (Kenwood). This was removed, covered, shaken vigorously for 15 minutes and filtered using Whatman No. 1 filter paper. The filtrate was used for proximate analysis and for the determination of ascorbic acid and glucose concentrations. The extract was used for the analysis of $\beta$-carotene concentrations. The same procedure was used for the determination of ascorbic acid and glucose concentrations in the extracts except that the extractants used were isopropyl alcohol and ether (Ojiako and Akubugwo, 1997).

\section{Proximate analysis}

The proximate analysis of the guava pulp extract for crude protein, crude fibre, and fat contents were determined using the methods described by Pearson (1976). Total ash content was determined by furnace incineration using the method of James (1995). Moisture and carbohydrate contents 
were determined using the method described by AOAC (2000).

\section{Elemental analysis}

The minerals: calcium, potassium, phosphorus, sodium, magnesium and iron were determined using the Buck scientific atomic absorption / emission spectrometer 200 A.

Evaluation of ascorbic acid, glucose and $\beta$ carotene concentrations

The concentration of ascorbic acid was determined by the methods of Ball (1994). Glucose concentration was determined using glucose oxidase assay kit according to the methods of Trinder (1969). $\beta$-Carotene concentration was determined using the method of Ojiako and Akubugwu (1997). In the chemical estimation of $\beta$-carotene, cognizance is taken of the fact that in biological systems, especially in plants, carotenoids often occur in association with lipid material, the evaluation of the concentration is preceded by a saponification process and the extraction with ether which removes the non saponifiable $\beta$-carotene from the saponifiable fraction. The method is specific for $\beta$-carotene.

\section{Statistical Analysis:}

Data obtained were expressed as means \pm standard deviation and analyzed using student's t' test. Values for $\mathrm{p}<0.05$ were taken to be statistically significant (Parker, 1979). The means were separated usnig Genstat for windows (Genstat, 2005).

\section{RESULTS}

The result of the effect of petroleum hydrocarbon pollution on the nutritional value of ripe guava fruits harvested from the two localities, Egbema and Mbaise, revealed that there were no significant ( $\mathrm{p} \geq 0.05$ ) differences in the mean values obtained for proximate compositions: Calcium, phosphorus, iron, magnesium, potassium and sodium (Table 1). The same trend was observed in the mean values for mineral elements obtained from guava fruits from both localities (Table 2). There was no significant $(\mathrm{p} \geq 0.05)$ difference observed in the glucose concentration in guava fruit pulp from Mbaise and Egbema (Table 3). However, mean values obtained for ascorbic acid and $\beta$-carotene concentration in guava fruit pulp from Egbema were significantly $(\mathrm{p}<0.05)$ lower than those harvested from Mbaise (Table 3). The reduction in the concentrations of ascorbic acid $173.28 \pm 0.77 \mathrm{mg} / 100 \mathrm{~g}$ and $\beta$-carotene $204.6 \pm 7.92 \mathrm{Icl} / 100$ grams for the red guava fruit variety was due to petroleum hydrocarbon pollution going on in that area.

\section{DISCUSSION}

The major nutritional composition of guava fruit pulp extract was found to include water, carbohydrate, protein and vitamins C and A (Sampson, 1986). Although the proximate composition of guava pulp extract showed a fairly poor nutrient composition compared to other common vegetables such as Amaranthus hybridus (Nwaogu et al., 2006). The results obtained for carbohydrate and crude fibre agrees with the work of Sampson, 1986. The guava fruit also contains adequate concentrations of vitamins $\mathrm{C}$ and A. Vitamin $\mathrm{C}$ has anti-infective properties, promote wound healing, help to boost the immune system. Vitamin A on the other hand, helps to maintain good sight and prevent disease of the eyes. Both vitamins have antioxidant properties (Wright, 2002).

The mineral composition of the fruit pulp reveals that the fruit is a source of calcium, potassium, magnesium, phosphorus, sodium and iron. These minerals play important roles in diverse metabolic activities.

Oil exploration and gas flaring have contributed to the petroleum hydrocarbon pollution level in Egbema. Definitely, the ecosystem has received the impact of pollution. Plants growing in such environment have over the years taken in a large dose of pollutants which invariably has affected the nutritional values of guava fruits grown in such environment. 
Table 1: Mineral compositions of ripe red guava (Psidium guajava) pulp extract from Mbaise and Egbema $(\mathrm{mg} / 100 \mathrm{~g})$.

\begin{tabular}{lcc}
\hline \multicolumn{1}{c}{ Mineral } & Mbaise & Egbema \\
\hline Calcium & $13.05 \pm 0.08$ & $12.80 \pm 0.05$ \\
Phosphorus & $23.90 \pm 0.08$ & $20.50 \pm 0.07$ \\
Iron & $0.50 \pm 0.10$ & $0.30 \pm 0.10$ \\
Magnesium & $10.00 \pm 0.20$ & $9.00 \pm 0.10$ \\
Potassium & $242.00 \pm 7.20$ & $240.50 \pm 6.40$ \\
Sodium & $3.00 \pm 0.05$ & $3.10 \pm 0.04$ \\
\hline Values are Means \pm S.D of five determinations. & &
\end{tabular}

Table 2: Proximate composition of ripe red guava (Psidium guajava) pulp extract from Mbaise and Egbema (g/ $100 \mathrm{~g}$ edible portion).

\begin{tabular}{lcc}
\hline Proximate & \multicolumn{2}{c}{ Mean Composition } \\
\cline { 2 - 3 } Composition & Mbaise & Egbema \\
\hline Ash & $0.70 \pm 0.01$ & $0.60 \pm 0.02$ \\
Carbohydrate & $10.00 \pm 1.02$ & $9.02 \pm 1.02$ \\
Crude protein & $0.90 \pm 0.22$ & $0.70 \pm 0.11$ \\
Crude fibre & $5.50 \pm 0.04$ & $5.40 \pm 0.03$ \\
Fats & $0.50 \pm 0.01$ & $0.40 \pm 0.02$ \\
Moisture content & $86.00 \pm 0.11$ & $84.00 \pm 0.04$ \\
\hline
\end{tabular}

Values are Means \pm SD of five determinations.

Table 3: Effect of petroleum hydrocarbon pollution on the ascorbic acid, $\beta$-carotene and glucose concentrations of red and white ripe guava (Psidium guajava) pulp extracts from Mbaise and Egbema.

\begin{tabular}{clcll}
\hline Location & $\begin{array}{l}\text { Variety } \\
(\mathbf{m g} / \mathbf{1 0 0} \mathbf{~ g})\end{array}$ & $\begin{array}{c}\text { Ascorbic acid } \\
(\mathbf{I U / 1 0 0} \mathbf{g})\end{array}$ & $\begin{array}{l}\boldsymbol{\beta} \text {-carotene } \\
(\mathbf{g} / \mathbf{1 0 0} \mathbf{g})\end{array}$ & Glucose \\
\hline \multirow{2}{*}{ Mbaise } & Red & $189.20 \pm 1.23$ & $249.60 \pm \ldots 13.19$ & $2.90 \pm 0.15$ \\
& White & $180.29 \pm 1.18$ & $228.54 \pm 23.57$ & $2.39 \pm 0.17$ \\
\hline \multirow{2}{*}{ Egbema } & Red & $173.28 \pm 0.77$ & $204.60 \pm 7.92$ & $2.75 \pm 0.14$ \\
& White & $164.75 \pm 0.89$ & $173.47 \pm 8.80$ & $2.60 \pm 0.07$ \\
\hline
\end{tabular}

Values are Means \pm SD of five determinations.

Ascorbic acid is a water-soluble antioxidant molecule, which scavenges reactive intermediates in the soluble cytoplasm and intracellular environment (Mckee and Mckee, 1999). As a cellular reductant, it readily donates electrons to reduce reactive intermediates in the cellular environment and is converted to dehydroscorbic acid, its oxidized form.
Petroleum hydrocarbon-induced pollution in Egbema reduced the mean concentration of ascorbic acid in fresh ripe guava collected from Egbema when compared to the values from the samples from Mbaise. This observed reduction in ascorbic acid concentration due to pollution in the environment could be attributed to the involvement of ascorbic acid as an antioxidant 
used to mop up reactive intermediates thereby reducing its concentration. This observation agrees with the reports of Levine (1986).

$\beta$-carotene is a pro-vitaminA usually found in plants. It consists of two molecules of retinal joined at the aldehyde end of their carbon chain (Nelson and Cox, 2000). $\beta$ carotenes play important roles in plants by protecting their photosystems from oxidative damages. They do this by direct quenching of the triplet oxygen in the chlorophyll which would prevent the generation of singlet oxygen (Ajay et al, 2002; Foyer, 1993). During stress condition, the concentration of reactive intermediates in the plant tissues activates the defence mechanisms for the scavenging of reactive intermediates. The mechanism is mediated by $\beta$-carotene and other antioxidants thereby reducing their concentrations in the fruits from Egbema when compare to their identical samples from Mbaise.

The result of glucose concentrations in the guava pulp varieties from Umudike Egbema did not differ significantly from those from Uvuru Mbaise (Table 3). Silbergeld (1974) reported that glucose could be a sensitive indicator of environmental stress in fish due to pollution, although the samples and environments used for both studies were not the same and so can not be comparable.

It was specially observed that the concentrations of ascorbic acid, $\beta$-carotene and glucose obtained from this study were higher in the red variety of guava from both environments; the reason for this difference needs further investigation.

\section{Conclusion and recommendations}

It would follow that reduction in the concentrations of ascorbic acid and $\beta$-carotene in the fruit samples from Umudike Egbema can be an indication of oxidant and metabolic stress due to petroleum hydrocarbon pollution in Egbema. Results from the study also indicated that indiscriminate petroleum hydrocarbon pollution on soil has significant effect on plant growth, yield and the quality of fruits produced. It is the opinion of the authors that: greater environmental consciousness should be instilled into oil company operators through legislation. In addition, research towards devising a simple method of remediation of soil after oil pollution should be encouraged to reduce the detrimental effects of petroleum hydrocarbon pollution on our soils.

\section{REFERENCES}

Ajay A, Sairam RK, Srivastava GC. 2002. Oxidative stress and antioxidant systems in plants. Current Science, 82(10): 12271238.

AOAC. 2000. Official Methods of Analysis. Association of Official Analytical Chemist: Washington DC.

Baker JM. 1970. The effect of oil on plants. Environ. Pollut., 1: 27 - 44.

Ball GFM. 1994. Water Soluble Vitamin Assay in Human Nutrition. Chapman and Hall: New York; 122- 123.

Ekpo MA, Nwankpa LI. 2005. Effect of crude on microorganisms and growth of ginger (Zingba officinate) in the tropics. Journal of Sustainable Tropical Agricultural Research, 16: 67 -71.

Epstein E. 1972. Mineral Nutrition of Plants, Principles and Perspective. John Willey and Sons Inc: New York; 412-414.

Foyer CH. 1993. Antioxidants in Higher Plants, Alscher RG, Hess JL (eds) CRC Press: Boca Raton, Florida; 31-58.

Genstat. 2005. Genstat for windows release 4.24DE discovery edn. Hemel Hempstead : VSN international.

Gill LS, Sandate RMA. 1974. Effect of foliarly applied CCC on the growth of Phaseolus aureus. Rjexb - mung on green gram. Bangladesh J. Biol. Science, 15: $35-40$.

Glouse AKM, Saidi HAA. 1980. Effect of pollution on the foliar organs of Callistemon citrinus. Staf. F. J. Sci. Res., 2: 207-209.

James CS. 1995. Analytical Chemistry of Foods. Chapman and Hall: New York; $52-55$ 
Jimenez EA, Rincon MA, Pulido RI, Saura Calixto F. 2001. Guava fruits (Psdium guajava) as a new source of antioxidant dietary fibre. J. African Food Chem., 49(11): 5489- 5493.

Kori-Siakpere O. 1998. Petroleum-induced attention in the African catfish (Claries gariepinus). Nig. J. Sci Environ., 49:5556.

Levine M. 1986. New concepts in the biology and biochemistry of ascorbic acid. New Engl. J. Medicine, 314: 892- 903.

Mckee T, Mckee JR. 1999. Biochemistry, An Introduction (2nd edn); 210 -219.

Nelson DC, Cox MN. 2000. Lehninger Principles of Biochemistry (3rd edn). Worth Pub: New York; 548-566.

Nwaogu LA, Ujowundu CO, Mgbemena AI. 2006. Studies on the nutritional and phytochemical composition of Amaranthus hybridus leaves. Bio-Res., 4: 28-31.

Odiete WO. 1999. Envrionmental Physiology of Animals and Pollution. Diversified Resource Ltd: Lagos; 50-52.

Odu CTI. 1972. Microbiology of soil contaminated petroleum hydrocarbon 111. Natural Rehabilitation and Reclamation of soils affected. Institute of Petroleum Technology Publication. pp 77-102.

Ojiako OA, Akubugwo EI. 1997. An Introductory Approach to Practical Biochemistry. CRC Publication: Owerri Nigeria; 103-107.

Parker RE. 1979. Introductory Statistics for Biology ( $2^{\text {nd }}$ edn). Arnold Publisher Ltd: London; $18-30$.
Pearson D. 1976. The Chemical Analysis of Foods. Chivah Livingstone Edinburgh; 37.

Rowell MJ. 1977. The Effects of crude oil spill on soils. A review of literature 1. The Reclamation of Agricultural soil after oil spills. part 1. Department of soil science, University of Alberta Canada, Canada. pp 33-355.

Sampson JA. 1986. Tropical Fruits (2nd edn). Longman Singapore Publisher Ltd; 270274.

Silbergeld EK. 1974. Blood glucose: A sensitive indicator of environmental Stress in fish. Bull. Environ. Contamin. Toxicol., 11: 20-25.

Smith B, Stachowish M, Volken - Burgh E. 1989. Cellular processes limiting growth in plants under hypoxic root stress. Experimental Botany, 40: 89-94.

Sofowara A. 1983. Medicinal Plants and Traditional Medicine in Africa. John Willey and Sons Ltd: Chichester; 256258.

Trinder P. 1969. Determination of glucose oxidase with an alternative oxygen acceptor. Ann. Clin. Biochem., 6: 24-27.

Udo EJ, Fayemi AA. 1975. The effect of oil pollution of soil on germination, growth and nutrient uptake of corn. J. Environ. Qual., 4: 537-540.

Umoh IB. 1998. Commonly consumed fruits in Nigeria. In Nutritional Quality of Plant Foods, Osagle AU, Eka OU (eds). Ambik Press: Benin City, Nigeria; 84-131.

Wright K. 2002. Healing Foods. Geddes and Grosset: Scotland; 8-31. 